\title{
Continuous prayer in Catherine of Siena
}

Author:
Diana L. Villegas ${ }^{1}$
Affiliation:
'Faculty of Theology and
Religion, University of the
Free State, South Africa
Corresponding author:
Diana Villegas,
dianavilsa@gmail.com
Dates:
Received: 26 Apr. 2017
Accepted: 26 June 2017
Published: 14 Aug. 2017
How to cite this article:
Villegas, D.L., 2017,
'Continuous prayer in
Catherine of Siena', HTS
Teologiese Studies/
Theological Studies 73(3),
a4611. https://doi.org/
10.4102/hts.v73i3.4611
Copyright:
○ 2017. The Authors.
Licensee: AOSIS. This work
is licensed under the
Creative Commons
Attribution License.

Attribution License.

Catherine of Siena offers considerable wisdom regarding continuous prayer. However, this wisdom in not well known because it is scattered among her texts, including over 373 letters, and is expressed in images and metaphors, the product of oral communication by a 14thcentury woman with no formal education. Through a literary analysis of original texts, I will show the interconnection among the meanings of her symbolic communications, offering a narrative about continuous prayer. I will explore the meaning of inner cell and time spent in this cell for knowledge of self and God. I will show how this dual knowledge results in transformation of the deepest motivation at the core of the person. Living consciously and for God's kingdom out of this transformed core of the self constitutes continuous prayer.

\section{Introduction}

Catherine of Siena, a 14th-century laywoman with no formal education, offers profound wisdom regarding continuous prayer, wisdom that is valuable and applicable in the 21st century. However, this wisdom is not well known because it cannot be easily culled by a straightforward reading of her texts, which are full of images and metaphors. Further, the fullness and complexity of her wisdom is scattered among her texts and requires interpretation. One of her images is the cell of self-knowledge, a metaphor for an inner experience or place of consciousness. This image and those that overlap and intersect offer a key to the most significant themes of Catherine's wisdom regarding the spiritual journey and unlock her wisdom regarding continuous prayer. I will examine the image of cell and the images, metaphors and language related to spending time in the cell. Through a literary analysis, I will show the interconnection among the meanings of her symbolic communications so that scattered texts can be woven into a narrative about continuous prayer. ${ }^{1}$

\section{Historical context}

Catherine's teaching on continuous prayer is both original and congruent with a long Christian tradition. Volumes have been written on prayer and on the related terms mysticism and contemplative prayer, both of which are related to the concept of continuous prayer; these terms all have multiple connotations depending on the tradition and/or historical period to which they refer. ${ }^{2}$ It is beyond the scope of this essay to place Catherine in this lengthy and multi-faceted historical perspective. Accordingly, I will focus only on essential elements of the tradition regarding continuous prayer. Before doing so, I define how I use the term prayer because this term itself has many connotations.

Prayer is most essentially a conscious, intentional opening of oneself to one's capacity for transcendence in an act of hope and faith that God is present in that transcendence and responds in a saving manner (Rahner 1975:1275): 'All positive religious acts which are directly and explicitly related, both knowingly and willingly, to God may be called prayer' (Rahner 1975:1275). This understanding presupposes that all human persons have a transcendent dimension to their identity where God is present. Catherine's wisdom on prayer and continuous prayer is fully congruent with this description of prayer from a contemporary systematic theology perspective.

\section{Continuous prayer in the Christian tradition}

Continuous prayer is referenced in Scripture (Lk 18:1; 1 Thess 5:17) and has existed since the earliest days of Christianity. Augustine referred to 'remembering God' as turning to consciousness of 1.Orazione continua, continuous prayer, appears 104 times in her letters.

2.The history of Christian spirituality has included debates regarding levels of prayer and contemplation and how these are related to holiness (see summary in Villegas 2012:51-55); there are debates about what constitutes mysticism and how this is related to contemplative prayer (see McGinn 1997:xi-xx). In addition, contemporary contemplative studies are contributing related research (Sherman 2014:1275).

Note: This article was originally presented as a paper at a Conference on continuous prayer sponsored by the Society for the Study of Christian Spirituality and the Center for the Academic Study of Christian Spirituality, Zurich (26-27 June 2017). 
God's presence and he taught that the depth of desire for God was the basis for developing such consciousness in a continuous manner (Gilson 1960:103; Leclercq 1985:415). From the earliest centuries, a spirituality of continuous prayer, meaning 'remembering God', became associated with monasticism. In both the East and West, hermits and then monks withdrew from ordinary human cultural contexts to live in an isolated, remote place cultivating the practice of prayer, spiritual reading and other spiritual exercises in order to foster the ability to live a life of continuous presence to God:

The state of prayer could and had to be habitual and continuous. It was constituted by an enduring attitude of meditation and attentiveness to God, as a result of which everything became prayer and longing. (Leclercq 1985:417, 23 [author's own italics])

The spirituality of Eastern monasticism from its earliest days also understood continuous prayer as a way of life, the fruit of transformation rather than as a particular practice:

Prayer is to be not merely one activity among others but the activity of our entire existence, a dimension present in everything else that we undertake ... It should constitute not so much something that we do from time to time as something that we are all the time. (Ware 1985:395) ${ }^{3}$

As in Western monasticism, withdrawal from the world and the practice of spiritual exercises were to assist the monk or hermit to confront his inner self, surrender this to God and thus be transformed by this form of encounter.

Particularly through the Eastern Monastic tradition, contemporary spiritual seekers have been exposed to a practice associated in our time with continuous prayer, namely the Jesus Prayer. ${ }^{4}$ The repetition of a set of words such as 'Jesus, have mercy on $\mathrm{me}^{\prime}$ throughout the day invites the person to develop a frequent and deep connection to God.

This brief historical summary highlights that continuous prayer has referred to living life in such a way that we enter easily into conscious connection with God throughout the day. This ability is the fruit of a long-term journey of spiritual exercises that have allowed God to transform our consciousness and way of living. Traditionally, then, continuous prayer is not primarily a set of practices or practice such as the Jesus Prayer, but a way of life, 'something that we are all the time' (see Ware 1985). As we shall see, Catherine's teaching is similar to the monastic spirituality of continuous prayer, but it is a spirituality for all to live in daily life, not just for life in a monastery.

\section{Catherine's works and literary style}

As context for exploration of Catherine's images for prayer and continuous prayer, it is important to understand the nature of her texts and the source of her wisdom. Her

3.See Ware's full article for a more detailed discussion of Eastern Monasticism, continuous prayer and a discussion of the Jesus Prayer. Also, see Noble (2015).

4.The spirituality of monastic hesychasm comes to us through The Way of the Pilgrim (Wiseman 2006:132-35), a 19th-century Russian adaptation of a long Eastern tradition. works consist of a book-length work, The Dialogue, a number of prayers and at least 373 letters (11 have not been officially numbered). ${ }^{5}$ She learned to read around age 19 or 20 and may have learned to write only in the last years before her death at 33, so that her works were mostly dictated, some while she was in ecstasy. ${ }^{6}$ Accordingly, her insights are expressed in an image- and metaphor-laden oral communication with shifting and overlapping connotations from one text to the next. Her wisdom, then, is not expressed in an organised, linear presentation, let alone a systematic manner.

\section{Formation}

Catherine's wisdom is not the product of formal education, so her mind was not formed to ponder with any form of logic. Thus, her reflections about life, spirituality and theology are the product of an intuitive process combining the mostly oral formation she received with the depth of her relationship with God or mystical experience. She absorbed spirituality and doctrine listening to the Divine Office, mostly psalms and Scripture readings. She listened to the readings at Mass and the preaching of the Dominican priests at her local church and eventually she learned through personal discussions with various spiritual directors and guides. She spent a great deal of time pondering this oral wisdom, internally chewing on it and allowed it to intertwine with the inspiration of the Holy Spirit. From this inner process came the images and metaphors in which she communicated her wisdom to those who took down her dictation.

The meaning of her images and metaphors can vary from text to text and a given image or metaphor can have more than one meaning, rendering the presentation and organisation of any theme in her work a great challenge. In the end, however, the kernels of wisdom found in an exploration of each image and metaphor when added together leave us with quite a coherent and profound teaching about continuous prayer.

I will present the different meanings of cell and the dynamics of spending time in the cell to know self and God. I will discuss Catherine's perspective and language on transformation, especially her teaching about conversion through the dual knowledge of God and self. Through further analysis of her images and language, we will see that this transformation makes one able to easily attune one's consciousness to God, enabling one to act materially and spiritually out of capacity for love, which for Catherine is continuous prayer.

5. Research for this essay is based on the original texts available in digital form (Catherine of Siena 2002), which include the critical edition of The Dialogue published by Giuliana Cavallini (Catherine of Siena 1995) and the latest critica published by Giuliana Cavallini (Catherine of Siena 1995) and the latest critical edition of the letters by Antonio Volpato. The Dialogue was completed in 1378 when Catherine was 31 (she died at the age of 33). There are a few letters thought to predate 1370 , but most of those available to us are dated between 1374 and
1380 (the year of her death). 6.For a historical literary analysis of Catherine's works, see Tylus (2009). For a summary discussion in English, see Noffke (1996:38-42). 


\section{The cell}

Already in the first paragraph of The Dialogue, we note the importance of the image of cell and the metaphor of entering into the cell as key to understanding Catherine's wisdom on prayer and continuous prayer:

She [the person] has for some time exercised herself in virtue and has become accustomed to dwelling in the cell of self-knowledge in order to know better God's goodness toward her, since upon knowledge follows love. And loving, she seeks to pursue truth and clothe herself in it. But there is no way she can so savor and be enlightened by this truth as in continual humble prayer, grounded in the knowledge of herself and of God. (Catherine of Siena $1980: 1.25)^{7}$

This sentence gives us the key to the reason I use the image of cell as a path into the whole complex of Catherine's teaching on prayer. Continuous prayer is grounded in knowledge of self and of God. In turn, these intertwined forms of knowledge are acquired in the cell or inner dwelling. Spending time in the cell or inner dwelling in order to be transformed through connection to God and self before God is 'the mother of prayer', and issues in living continuous prayer. 'Go into the dwelling of the cell where you taste the mother of prayer; this prayer keeps you living and growing in virtue' (Letter 104), ${ }^{8}$ Catherine exhorts Raymond, her confessor and dear friend.

\section{Meaning of cell}

Catherine's creative use of 'cell' as a symbol refers to an interior experience, an interior locus of consciousness where God is encountered as we encounter ourselves before God, and through time in the cell the spiritual journey unfolds. Before we explore in detail Catherine's teaching about the cell and the spiritual journey, it is important to keep in mind what she means by knowledge of self, ${ }^{9}$ particularly because in our contemporary culture this concept has psychological connotations which are not part of Catherine's world view, and therefore of her vocabulary. For Catherine, selfknowledge involves recognition that we depend for our whole being on God, that God is our source of life. Further, self-knowledge means we come to have a felt understanding of our vulnerability to act in sinful or disordered ways because of our foundational tendency to selfish self-love. On the other side of this experience, we taste God's unfathomable, merciful love, which is the transforming force.

\section{The person is the cell}

In one of her letters, Catherine literally says that the person is the cell. She exhorts a Benedictine Nun as follows:

This is what you must do. Go to the room, the cell of selfknowledge.

7.Citations to Dialogue: chapter followed by page numbers of English translation.

8.Translations of the Letters are mine unless reference is made to Suzanne Noffke's translation, which includes four volumes (Catherine of Siena 2000-2008).

9.In a Ph.D. dissertation, Patricia Fresen studied the development of Catherine's wisdom regarding self-knowledge (1996).
... Go into the cell and go to bed, in which bed you will find God's goodness, which is within you, [you are the] cell. (Letter 73)

Note she literally addresses the person as 'cell.' If one is the cell, then this place of consciousness is a central dimension of one's identity. Or, put another way, the place of quiet where one can know oneself and God is the depth of one's consciousness. In order to enter into this depth of consciousness, the person is exhorted to 'go to bed', an image for slowing down, resting and closing one's eyes. In other words, the cell as space of consciousness is a place of inner quiet and restfulness where God is found and the 'location' of this space is the core of one's identity.

Cell of self-knowledge is the most frequently used term for this inner dwelling, ${ }^{10}$ but there are other related images, namely house of self-knowledge, cell of the soul, cell of the side of Christ and sometimes simply cell.

\section{House of self-knowledge}

When combined with knowledge of self, 'house' is an alternative term for cell. Catherine speaks of going into the house of self-knowledge as equivalent to entering within oneself. She tells a monk, 'He who wants to follow [Christ crucified] enters quickly within himself. In this house ...' (Letter 154). In another letter, she exhorts Raymond to enter into a place of inner quiet, the house of self-knowledge, where he can know that he is 'spouse of the Truth', one of her powerful, repeated metaphors indicating the intimacy to which God calls us. 'You need to know the Truth and desire to be the spouse of Truth. Where [does this happen]? In the house of self-knowledge' (Letter 102). In this house, we experience God as Christ crucified and as the Truth. These designations for God highlight the transforming power of God: leading us to know and embrace the cross and to know the truth. Both these dimensions of God are learned as we spend time entering into our deepest consciousness and there also face ourselves.

\section{The cell of the soul}

In various letters Catherine refers to the 'cell of the soul', adding nuance to the meaning of cell. In one of her earliest letters to Tommaso della Fonte, a cousin and Dominican, she writes, 'dwell within the cell of your soul' (Letter 41). Soul suggests the core of the self, the centre of one's transcendental identity so that going into the cell of the soul implies turning one's consciousness to the place where our transcendent identity encounters the presence of God. In this sense, this metaphor is similar to the one stating that the person is the cell.

In another passage, Catherine states that the soul is heaven (Letter 353). ${ }^{11}$ Heaven has the connotation of a place where

10.The precise metaphor............................................................................... and becomes common after 1377 when most of Catherine's letters and The Dialogue were created. See Catherine of Siena (2000-2008:1.306.n.18).

11.Catherine uses soul with the commonly understood meaning in her day, namely the core transcendent dimension of the person's identity. 
one is finally united fully to God's love and where transformation to truth and love is completed. Thus, if our soul is like heaven, when our consciousness is directed to our deepest, transcendent self we make a most intimate and full connection with God whose desire and aim is our transformation.

\section{Cell of the side of Christ}

The cell of the side of Christ is an image that evokes the blood and water poured out on the Cross (Jn 19:34), and therefore points to God's redemptive love. Catherine urges a group of novices:

[Go into] the cell of Christ's side where you will find knowledge of yourself and of God's goodness ... get up with deep and burning desire; go, go inside and stay in this sweet room where no human person or demon can separate you from grace ... and from seeing and delighting in God. (Letter 36)

Here entering the cell involves turning one's consciousness to contemplation of or resting in the image of Christ's side, allowing such contemplation to reach the depth of one's being thus infusing understanding of the central Christian belief that Jesus gave himself for us out of love; from such contemplation follows transformation.

Catherine's wisdom here and elsewhere suggests that we are likely to deceive ourselves less if we face ourselves while deeply in touch with the meaning of God's giving of God's life for us in Christ. God's self-giving love shines an inner light that protects from self-deception, but it is a truth that must be experienced in the core places of the self; it is not a matter of intellectual knowledge or an assent of faith that has not passed through knowledge of our need for God.

\section{Time in the cell}

From Catherine's perspective, spending time in the quiet necessary to connect to the place of consciousness at the core of one's identity is so central to the spiritual journey that in a majority of her letters she urges and even orders her correspondents to enter into the cell and spend time there. For instance, she writes to one of her nieces, a nun, 'I order you, dearest daughter that you always dwell in the house of self-knowledge where we find the angelic food of Gods tremendous desire for us' (Letter 26). To the mother of one of her favourite male disciples, she writes 'with desire to see you make a dwelling in the cell of knowledge of self, so that you may reach perfect love ... This love is found by the soul who knows herself' (Letter 241). ${ }^{12}$

In order to spend time in the inner cell, the person must also spend time in the actual or physical cell, 'cella attuale', ${ }^{13}$ which for hermits, monks or religious is literally their

12.See also Letters 37 and 76 .

13.While Catherine most often uses the term cella attuale for a literal, physical cell, in contexts where it is clear cell means a physical room she just uses the word 'cell'. Noffke translates attuale as physical or material. bedroom (the common meaning of 'cell'). However, for the many correspondents who were laypersons, the actual, physical cell had the symbolic meaning of a physical space set aside for quiet. The centrality of spending time in a quiet physical space is seen in the following exhortation to a Benedictine monk, but it is the sort of exhortation made to a large number of her correspondents, many of whom were laypersons of both sexes and of many walks of life: ${ }^{14}$

Why is staying away from your material cell so unwholesome? Because before you abandon your material cell, you have already abandoned the spiritual cell of self-knowledge. If this weren't so, you would have known how weak you are, and that weakness would have been a signal for you to stay in your cell [the physical cell], not to leave it. (Letter 37, Catherine of Siena 2000-2008:3.15)

She warns that avoiding times of quiet is a sign that commitment is lacking to the all-important focus on consciousness of one's need for God and the related presence to God's love. If we are not in touch with our woundedness and sinfulness, we lose track of the necessity of spending time in quiet in order to allow God's love and mercy to act with our conscious cooperation; we also lose the desire to reach out to God present within. And because Catherine's wisdom is seldom linear, she points out that some experience of God's desire for us is necessary to develop a 'love for' or felt desire to spend time in the inner cell, that is, a desire for time in quiet. 'If the person had not first spent time in the spiritual cell, he would not have developed a desire for the actual cell nor would he love this cell' (Letter 37). In other words, there is an interrelated dynamic between having an experience of God's love and an encounter with our need for God.

\section{Balance knowledge of God and knowledge of self}

The interrelationship between the encounter with self at the core of our being and the encounter with God's love is a central dynamic of Catherine's wisdom. The importance of this interrelationship is seen through the apparently paradoxical image that knowledge of self is one cell, knowledge of God another, yet the two together are one cell. With this symbolic image, Catherine highlights that while separate forms of inner experience, knowledge of self and God must be experienced together in order to be fruitful and life giving. We see this wisdom in a letter to Alessa, one of her spiritual daughters:

Then make a spiritual dwelling place which you can carry with you at all times. This is the cell of true knowledge of yourself, where you find the knowledge of God's goodness towards you. So these [two forms of knowledge] are two cells in one. When you dwell in one of these it is important for you to dwell in the other at the same time, otherwise your soul would become confused or proud. (Letter 49)

14. Her correspondents included Popes, cardinals; kings and queens; noblemen and women; doctors and judges; ordinary, married and unmarried lay men and women women; doctors and judges; ordinary, married and unmarried lay men and women;
as well, of course, monks and nuns, priests, hermits and other celibates committed as well, of course, monks and nuns, priests, hermits and other celibates committed
to the service of God. 
And in order to make herself this spiritual dwelling with to two cells in one, Alessa is advised to spend time in the actual cell.

Catherine explains to Alessa that experiencing God's love alone can lead to pride, a form of self-centredness. That is, without the balance of knowing our need for God, we might conclude we have reached a spiritual superiority, or have achieved a holy end. We could become self-satisfied in experiencing the consolation of God's love without the recognition of how this love is meant to transform and flower into care for the good of the other. On the other hand, we would suffer inner darkness and confusion if we only acquired consciousness of our need and sinfulness. ${ }^{15}$ We could become discouraged and despondent, lacking in hope.

\section{Catherine offers this same wisdom to Costanza, a nun:}

I would like you to see that you are not, that you are neglectful and lacking in knowledge. However, I do not want you to see this through the darkness of confusion. Rather I want you to see this through the light of God's infinite goodness, which is within yourself. (Letter 73)

Catherine's spirituality highlights the merciful, gentle, forgiving love of God that desires our transformation through love. In this case, God's goodness is a light which with goodness illuminates that which is dark within us. Catherine would never advise to go within the self to know our need and sinfulness without the balance of mercy and unconditional love. Thus, in the above letter, she helps her correspondent understand that in order to experience what God's goodness is like, she must pass through knowledge of her sinfulness.

Another nuance of the dynamic between knowledge of self and of God can be gleaned from another creative image, that of the cell as a well. In a letter to Tommaso, her cousin and a Dominican priest Catherine teaches that:

the cell is like a well in which there is earth as well as water. In the earth we can recognize our own poverty: we see that we are not. For we are not. We see that our being is from God ... As we discover the earth we get to the living water, the very core of the knowledge of God's true and gentle will, which desires nothing else but that we be made holy. So let us enter into the depths of the well. (Letter 41, Catherine of Siena 2000-2008:1.8)

The intimate relationship between knowledge of God and self involves passing through knowledge of our need for God in order to know that God is the living water, or source of life, for us. Metaphorically, then, by digging through, that is, facing the earth of our sinfulness and self-centeredness, we learn God is gentle and desires that we become Holy. For Catherine "being made Holy" implies transformation so that we learn the truth about ourselves, about God's love and through this process we become empowered to live up to our capacity for self-giving love and truth.
Through this layered image, Catherine highlights a significant aspect of knowledge of self, namely, that 'we are not', meaning that we depend on God for our very being, our very existence; we depend on God to actualise our deepest identity. This need for God in order to actualise the best of who we are is a foundational reality that we can only learn in the inner cell but it must be balanced by knowledge of God's goodness.

\section{Transformation}

Catherine, then, teaches that the interrelated knowledge of self before God and knowledge of God's love transforms. At the same time she emphasises that the transforming force is God's love itself, an important distinction. This distinction is evident in some of the symbolic language she uses for God's love.

\section{The nature of God's transforming love}

Most often, Catherine refers to God's love as carità, usually translated as charity; yet this translation with its English connotation misses the depth and breadth of Catherine's meaning. Carità is God's self-giving love, a love that comes from an unfathomable desire on the part of God to empower our capacities as his beloved images. In The Dialogue, Catherine refers to encountering God's charity as:

the knowledge that the person acquired knowing herself and my goodness within her where she experienced herself loved in an inexpressible and indescribable manner ... because I [God] loved you without being loved by you, even before you existed. (Dialogue, 88. [author's own translation])

In some texts, carità is compared to a fire; in others, love is burning charity. These metaphors of fire and burning charity are images that connote an intensity of love that consumes that which it touches, which is our sinful self, our self-centred self. As the fire of burning charity consumes our selfcentredness, it produces desire for the good of others and 'holy and loving desires'. She tells a Dominican, 'and in the knowledge of God, which he found within himself, he acquires the virtue of burning charity which produces holy and loving desires' (Letter 94). For Catherine the authentic experiential knowledge of God's love always has this consuming and, therefore, transforming quality. She expresses this wisdom to Alessa:

In the knowledge of God you will find the fire of divine charity. Where will you delight in his charity? On the cross, with the Immaculate Lamb, seeking his love and the good of souls. (Letter 49)

The transforming quality of carità means that through its reception we learn how to live self-giving love, symbolised by Jesus' giving of self on the cross. We become empowered to live carità in our relationships with others.

God's love is also a sweet mercy, which though a consoling image nevertheless effects change and growth such that the person is made capable of accomplishing God's will: 
in knowledge of yourself you will encounter the sweet mercy of the Holy Spirit, who is love itself and gives love ... in the cell of the soul you will find all of God, [emphasis mine] who gives such sweetness, consolation and refreshment that nothing that happens can disturb the person as she is [through this love] made capable of God's will. (Letter 214)

While the images are completely different in connotation than those of fire, or burning, the theme of God's love as transforming emerges again. Experiencing merciful love implies that the person has come to know her need for such mercy and in this need has known God's sweet, consoling and refreshing love, which heals her wounds and gently transforms her self-centredness. The experience of mercy is so important that the person comes to know all of God as Love, an image suggesting a great fullness of knowledge of God, as creator, as saviour, as gentle, transforming guide. Such fullness of knowledge of God converts the person into someone capable of following God's will. When the person is so transformed, she acquires a profound peace because she has 'removed all selfish self-love, and all those things that are outside of God's will' (Letter 241).

\section{Affetto and desire}

Also central to understanding Catherine's view of transformation is what she calls affetto, a word that functions symbolically and has a multiplicity of meanings at once. (No English word captures the meaning of this term which is usually translated as affection). Affetto means a combination of emotion, passion, desire, love, affectivity and will (where will means moving force its patristic and medieval meaning).${ }^{16}$ Together with desire, a term with which it overlaps, affetto refers to the depth of a person's self, where she is moved by a combination of what she most values and loves; affetto denotes, then, our deepest motivation. This place in the person is the home of charity, the capacity to love transformed by God. 'In the knowledge of yourself you will find the sweet mercy of the Holy Spirit; it is that part of God that is Love and bestows only love ... You will find this affetto in your soul as the will is love; all affetto and action is moved only by love' (Letter 241).

\section{Progression}

The progressive transformation of desire/affetto occurs through commitment to and perseverance in spending time in the cell or inner dwelling, and of course, through God's free gift of grace. Catherine depicts this advancement through a set of images that appear mostly in The Dialogue (more schematically in various letters). While the different sets of images overlap, one can nevertheless glean a pattern of growth. The general directionality of this progressive transformation is from self-centeredness, that is, from preoccupation with self to capacity to see what is good for others, to transformed desire/affetto so that what we choose mystique (1953:2288-2300) explores the history of the term. and desire is congruent with God's view of the good, be it our good, our neighbour's good or the community's good. ${ }^{17}$

\section{Continuous prayer}

Catherine teaches that continuous prayer is our desire/affetto when it is grounded in charity (carita)), that is, when affetto is an expression of the progressive transformation of the core of our motivation and perception. ${ }^{18}$ This transformation, we have seen, depends on fidelity and perseverance in spending time in the cell of knowledge of self and God. Catherine offers this wisdom to a Carthusian monk:

One [form of prayer] is continuous prayer, to which all persons are obligated. This is the true, holy desire grounded in charity towards God and our fellow human beings such that all actions towards our neighbors are done in God's honor. This desire prays always; that is affetto as charity prays continuously before its creator; this is at all times no matter where the person is or what she is doing ... This is the prayer to which the glorious apostle Paul invites us when he tells us to pray without ceasing. $(\text { Letter 154) })^{19}$

Through her symbolic communication, Catherine offers various nuances to this teaching. In this passage, affetto is personalised; in other words, affetto rooted in charity is the actor of continuous prayer. Because affetto refers to depth of motivation and will (moving force), saying that affetto is continuous prayer highlights that this moving force at the core of the self is continuous prayer. In other words, the way the person feels, thinks, acts and chooses when the core of the self is transformed by charity is a continuous prayer no matter what the person is doing or where she is. In a letter to Eugenia, her niece and a nun, Catherine repeats this teaching in different words:

The first [form of prayer] is continual prayer. I mean continual holy desire. This desire prays in God's presence in everything you do, because it directs to God's honor your every action, whether spiritual or physical. This is why it is called continual. (Letter 26, Catherine of Siena 2000-2008:4.193)

In this case, 'desire' characterised as continual is continuous prayer. That is, when our core motivation is transformed by carità, we desire that all we do, spiritually or materially, be for the glory of God, that is, for the good, the just, the ordered from God's perspective. In Biblical terms, our desire is ordered towards the actualisation of God's kingdom. This is continuous prayer.

In a letter to the abbess of a Florentine monastery, Catherine teaches that the transformation that blossoms into continuous prayer is progressive, as we grow in humility, which in

17.See Catherine of Siena (1980:chaps 26-61, 88-99; Letter 201). Scholars have studied the different sets of images and concluded that they overlap but are not identical. Two classical studies by Italian scholars of Catherine are Anodal (1972) and D'Urso (1971). I offer a summary in Villegas (1997:32-36).

18.Noffke (2003) asserts that in Catherine there is integrity between contemplative prayer and action, and the balanced interrelation of these is continuous prayer.

19.I have translated this passage as literally as possible to preserve Catherine's unique form of expression regarding a topic central to this essay. Noffke's translation reads, 'Such desire is constantly praying; I mean, the movement of charity in what reads, 'Such desire is constantly praying; I mean, the movement of charity in what
we do is praying continually before our Creator no matter where we are or when' we do is praying continually before our
(Catherine of Siena 2000-2008:4.51). 
Catherine means the knowledge of our need for God (already described in detail) and the experience of God's unfathomable love. At the same time, she reminds the abbess that such love is learned in the 'breast of Christ crucified', that is, by learning to live in a self-giving way and allowing suffering to be transformative: ${ }^{20}$

[T] here at the breast of Christ crucified they learn watchfulness and continual humble prayer. They are watchful not only over their physical eyes but over the eyes of their soul through knowledge of themselves, of their weakness and past wretchedness, and of God's gentle goodness within them, seeing that they are indescribably loved by their Creator. So little by little the virtue of humility follows and the blazing holy desire (emphasis added) which is the continual prayer of which Paul teaches us when he says that we should pray always, without interruption. And after holy desires follow the good holy actions which constitute uninterrupted prayer that never ceases doing good. (Letter 86. Catherine of Siena 2000-2008:4.286-7)

We see again in this passage that desire leading to action, when rooted in transformation is continuous prayer. The wisdom in this passage also points to the interior watchfulness or attentiveness (i.e., spending time in the cell) that is necessary for continuous prayer.

That prayer is continuous only as the fruit of transformation is emphasised in a text where she tells Francesco, the Carthusian that:

continuous humble prayer [is] made in the house of selfknowledge and knowledge of God's goodness. The soul [person] would obtain little fruit from continuous prayer made outside of this house, (emphasis added) for such prayer has as its basis humility, which is learned in this house. Such prayer is clothed in the fire of divine charity which is found in the knowledge of God acquired as the person experiences the light that shows her how boundlessly she is loved by Him. (Letter 154)

In telling us that continuous prayer is fruitful only when made in the house of self-knowledge and knowledge of God, Catherine is telling us, through her symbolic communication, that continuous prayer is not authentic unless it arises from a place within us that is rooted in a connection with God that has resulted over time in our transformation. Or put in different words, without transformation through time in the cell, one's spiritual and physical actions are unlikely to be congruent with God's will and there would not be continuous prayer. In other words, Catherine tells us again that continuous prayer is operative when out of the core of transformed desire/affetto we are present to God and to our deepest selves as we go about our daily life.

\section{Intercessory prayer as continuous prayer}

Intercessory prayer is one of the actions directed towards God's glory that is particularly effective when the fruit of continuous prayer. In a letter to a hermit, Niccolo, she urges

20.The limits of space in this essay have not made it possible to develop the theme of the transformative power of suffering lived in union with God, a significant theme in Catherine's texts. him to work for the good of others 'our fellow human beings, whom we must love' through intercessory prayer 'offering humble tears and continuous prayer before God for the salvation of all' (Letter 78). At the conclusion of The Dialogue, Christ says to Catherine, 'Now I invite you to weep ... And through your weeping and constant humble prayer I want to be merciful to the World' (Catherine of Siena 1980:166.363). In these passages, tears are both physical tears and a symbolic expression of the core of a person's affectivity. One of the set of images for progression in transformation from selfcentredness to capacity for charity is that of levels of tears. In that context, tears are symbolic of affetto and 'levels of tears' refers to different degrees of converted affetto/desire. Thus, when Catherine speaks of offering tears or weeping as part of continuous prayer, she is emphasising that when we consciously surrender the depth of transformed affetto to God for others, we are engaging in continuous prayer as a form of intercession.

\section{Summary}

Catherine's wisdom teaches that continuous prayer is a way of perceiving and acting, a way of living consciously out of a desire to follow God and bring about God's Kingdom. This becomes possible as one acquires a facility for turning one's consciousness to God and to respond to God's guidance in living a life of self-giving and care for the good of the world, the environment, our fellow human beings, our families and ourselves. Continuous prayer is the fruit of a progressive transformation resulting from an encounter with the God of love as we confront our need for God. That continuous prayer involves such transformation is a particularly important point to highlight for us contemporary seekers who might be inclined to focus on achievement of proficiency in prayer methods, or on the attainment of certain experiences or levels of consciousness.

Catherine's wisdom teaches a spirituality of continuous prayer that can be adapted to contemporary life. As we saw, she advocated continuous prayer for all persons (not just monks, priests or nuns), and she told her correspondents that continuous prayer should occur wherever we are and in whatever we are doing. How is this possible? Through commitment to a discipline of time spent in attentiveness to God's presence within us and to allowing this presence to transform us. The spiritual exercise par excellence that Catherine would recommend can best be illustrated by a contemporary analogy. If we imagine God's love and light as radio waves that are always reaching us, we can similarly imagine that we need to turn the radio on in order to hear these waves, God's Word. Turning on the radio once a day to listen to God would be equivalent to spending time in the inner cell as described by Catherine. She does not give particular guidelines or exercises in order to tune in to the radio (though she always recommends the recitation of the Divine Office and the Psalms). Rather, she encourages frequent time spent in quiet. We contemporary seekers can learn from exercises of centering prayer, repetitive prayer (such as the Jesus Prayer) or lectio divina that would foster 
this listening. Any exercise designed to 'turn on the radio' on a daily basis eventually results in ease of access to consciousness of God's presence, and to the process of knowledge of self and of God's transforming love described in this article.

Catherine's wisdom is congruent with the tradition of continuous prayer in that it involves Augustine's 'remembering God', it involves acquiring the inner quiet sought by the Eastern and Western hermits and monks. Further, her wisdom is congruent with the monastic ideal of continuous prayer as a way of life for following the Gospel. Perhaps, because she was a laywoman, she was innovative in her assertion that continuous prayer was not only possible for all persons, but she insisted that all persons were called to continuous prayer. ${ }^{21}$

\section{Acknowledgements Competing interests}

The author declares that she has no financial or personal relationships which may have inappropriately influenced her in writing this article.

\section{References}

Anodal, G., 1972, 'Le immagini del linguaggio cateriniano e le loro fonti: la scala', Rassegna di ascetica e mistica 23, 332-343.

Catherine of Siena, 1980, The dialogue, Paulist, New York.

21. Her call to continuous prayer for all persons is innovative for Western spirituality Ware points out that Eastern monastic writers asserted that continuous praye should be for all persons (Ware 1985:412).
Catherine of Siena, 1995, II Dialogo della divina provvidenza ovvero Libro della divina dottrina, G. Cavallini (ed.), Cantagalli, Siena.

Catherine of Siena, 2000-2008, The Letters of Catherine of Siena, Arizona Center for Medieval and Renaissance Studies, Tempe, AZ.

Catherine of Siena, 2002, 'Santa Caterina da Siena: Opera omnia', in F. Sbaffoni (ed.), $C D-R O M$, Provincia Romana dei Frati Predicatori, Pistoia.

Châtillon, J., 1953, 'Cor et cordis affectus au Moyen Age', Dictionnaire de spiritualité ascétique et mystique 22, 2280-2300.

D’Urso, G., 1971, II genio di Santa Caterina: Studi sulla sua dottrina e personalità, Edizioni cateriniane, Rome.

Fresen, P., 1996, The cell of self-knowledge in the writings of Catherine of Siena, University of South Africa.

Gilson, E., 1960, The Christian Philosophy of St. Augustine, Random House, New York.

Leclercq, J., 1985, 'Ways of prayer and contemplation: II Western', in B. Mcginn \& J. Meyendorff (eds.), Christian spirituality: Origen to the twelfth century, pp. 415-426, Crossroad, New York.

Mcginn, B., 1997, Foundations of mysticism, Crossroad, New York.

Noble, T., 2015, 'Ignatian and Hesychast spirituality: Praying together', St Vladimir's Theological Quarterly 59, 43-53.

Noffke, S., 1996, Catherine of Siena: Vision through a distant eye, Liturgical, Collegeville.

Noffke, S., 2003, 'Integrity learned in contemplation: Insights from Catherine of Siena', Religious Life Review 66-80.

Rahner, K., 1975, 'Prayer', in K. Rahner (ed.), Encyclopedia of theology: The concise Sacramentum Mundi, pp. 1268-1277, Seabury Press, New York.

Sherman, J.H., 2014, 'On the emerging field of contemplative studies and its relationship to the study of spirituality', Spiritus 14, 208-229. https://doi. org $/ 10.1353 /$ scs.2014.0031

Tylus, J., 2009, Reclaiming Catherine of Siena: Literacy, literature, and the signs of others, University of Chicago, Chicago, IL.

Villegas, D.L., 1997, 'Discernment in Catherine of Siena', Theological Studies 58, 19-38. https://doi.org/10.1177/004056399705800102

Villegas, D.L., 2012, The Christian path in a pluralistic world and the study of spirituality, Lexington Books, Lanham, MD.

Ware, K., 1985, 'Ways of prayer and contemplation: I Eastern', in B. Mcginn \& J. Meyendorff (eds.), Christian spirituality: Origins to the twelfth century, pp. 395-414, Crossroad, New York.

Wiseman, J.A., 2006, Spirituality and mysticism, Orbis, Maryknoll, NY 